\title{
Use of Several Natural Products from Selected Nicotiana Species to Prevent Black Shank Disease in Tobacco*
}

\author{
by \\ Antoaneta B. Kroumova, Ivan Artiouchine, and George J. Wagner \\ Kentucky Tobacco Research and Development Center (KTRDC), College of Agriculture, University of Kentucky, \\ Lexington, $K Y$, USA
}

\section{SUMMARY}

Black shank is a major annual disease threat to all types of tobacco worldwide. It is caused by the fungus Phytophthora parasitica var. nicotianae (PPN). The major tobacco growing areas in US - Kentucky, Tennessee and North Carolina can experience devastating losses, reaching in some fields up to $100 \%$. Thus far, the main approaches to control this disease have been creation of resistant varieties, fungicide treatments, and crop rotation. Some fungicides are reported to have negative effects on the environment. The goal of this work was to test the antifungal activity of several natural products that are synthesized by certain Nicotiana species, and secreted to the leaf surface. We hypothesized that phylloplanin, cis-abienol, labdenediol and sclareol can suppress PPN-race 0- and PPN-race 1caused disease in Burley tobaccos KY 14 and MS KY 14 $\times$ L8LC in the greenhouse. We developed methods for leaf surface extraction, spore preparation and soil drench application of the natural compounds tested. Experiments were performed on 5-8 week-old greenhouse grown seedlings. cis-Abienol showed high inhibitory properties toward the disease. Race 0 infection was completely subdued in KY 14 while race 1 infection was reduced by $70-80 \%$, and delayed by 6-10 days in KY 14 and MS KY14 × L8LC. Sclareol was very effective in inhibiting race 0 -caused disease in both tobacco cultivars. In MS KY $14 \times$ L8LC race 1 infection was inhibited while in KY 14 it was reduced by $85 \%$ and delayed by 6 days. Labdenediol reduced the disease by half in eight week-old KY 14 plants. Tobacco phylloplanin reduced plant infec- tion by both races by $50-60 \%$ and delayed the disease by 6-10 days. Phylloplanin was least suppressive in both tobacco cultivars. We consider sclareol to be the best candidate for future studies due to its antifungal properties and availability. cis-Abienol, despite its good antifungal activity, is not feasible for large-scale use due to the production and stability limitations. [Beitr. Tabakforsch. Int. 27 (2016) 113-125]

\section{ZUSAMMENFASSUNG}

Die Stängelgrundfäule stellt jährlich eine der größten Bedrohungen für alle Sorten von Tabak weltweit dar. Sie wird durch den Pilz Phytophthora parasitica var. nicotianae (PPN) verursacht. Die großen Tabakanbaugebiete in den US-Bundesstaaten Kentucky, Tennessee und North Carolina können durch sie verheerende Verluste erleiden, die auf manchen Feldern bis zu 100\% ausmachen. Hauptbekämpfungsmaßnahmen waren bisher die Züchtung resistenter Sorten, die Behandlung mit Fungiziden und der Fruchtwechsel. Bei manchen Fungiziden wurden nachteilige Auswirkungen auf die Umwelt berichtet. Ziel dieser Arbeit war es, die antimykotische Wirkung verschiedener natürlicher Produkte, die von bestimmten Nicotiana-Arten synthetisiert und auf die Blattoberfläche sekretiert werden, zu testen. Wir vermuteten, dass Phylloplanin, cis-Abienol, Labdenediol und Sclareol die durch die PPN-Rasse 0 und die PPN-Rasse 1 verursachte Erkrankung bei den BurleyTabaksorten KY 14 und MS KY $14 \times$ L8LC im Gewächshaus unterdrücken können. Wir haben Methoden für die 
Extraktion von Blattoberflächen, Präparation von Sporen und Boden-Tränkanwendung für die untersuchten natürlichen Verbindungen entwickelt. Die Versuche wurden an 5-8 Wochen alten Gewächshaus-Setzlingen durchgeführt. cis-Abienol zeigte im Hinblick auf die Krankheit starke Hemmeigenschaften. Die Infektion mit Rasse 0 wurde bei KY 14 vollständig bekämpft, während die Infektion durch Rasse 1 bei KY 14 und MS KY $14 \times$ L8LC um 70-80\% reduziert und um 6-10 Tage hinausgezögert wurde. Sclareol war bei beiden Tabaksorten sehr wirksam bei der Hemmung der durch Rasse 0 verursachten Krankheit. Bei MS KY $14 \times$ L8LC wurde die Infektion durch Rasse 1 unterbunden, während sie bei KY 14 um 85\% reduziert und um sechs Tage hinausgezögert wurde. Labdenediol reduzierte die Krankheit bei achtwöchigen KY 14-Pflanzen um die Hälfte. Tabak-Phylloplanin reduzierte die Infektion der Pflanzen mit beiden Rassen um 50-60\% und zögerte die Erkrankung um sechs bis zehn Tage hinaus. Phylloplanin erwies sich bei beiden Tabaksorten als am wenigsten suppressiv. Sclareol ist unserer Meinung nach aufgrund seiner antimykotischen Eigenschaften und Verfügbarkeit der beste Kandidat für zukünftige Studien. cis-Abienol ist, trotz guter antimykotischer Wirkung, wegen der Einschränkungen hinsichtlich Produktion und Stabilität für eine großflächige Anwendung nicht praktikabel. [Beitr. Tabakforsch. Int. 27 (2016) 113-125]

\section{RESUME}

La jambe noire est une maladie majeure qui menace annuellement tous les types de tabac au niveau mondial. Le responsable de cette pathologie végétale est le champignon Phytophthora parasitica var. nicotianae (PPN). Les principales régions tabacoles aux USA, à savoir le Kentucky, le Tennessee et la Caroline du Nord sont susceptibles de subir des pertes dévastatrices allant jusqu'à affecter la totalité de certains champs. A ce jour, les principales approches de maîtrise de cette maladie se sont fondées sur la création de variétés résistantes, des traitements fongicides et la rotation des cultures. Des rapports épinglent certains fongicides qui auraient des effets nocifs pour l'environnement. Le propos du présent travail est l'analyse de l'activité antifongique de diverses substances naturelles qui sont synthétisées par certaines variétés de Nicotiana et secrétées à la surface foliaire. Nous sommes partis de l'hypothèse que la phylloplanine, le cis-abiénol, le labdénédiol et le sclaréol pouvaient éradiquer la maladie causée par la PPN-race 0 et la PPN-race 1 dans les plants de tabac Burley KY 14 et MS KY $14 \times$ L8LC cultivés en serre. Nous avons mis au point des méthodes d'extraction à la surface de la feuille, de préparation des spores et d'application par mouillage des sols des composés naturels testés. Des expériences ont été menées sur les jeunes plants de cinq à huit semaines cultivés en serre. Le cis-abiénol a montré de grandes propriétés inhibitoires face à cette maladie. L'infection par la race 0 a été complètement vaincue dans le tabac KY 14 tandis que l'infection par la race 1 a été réduite de $70-80 \%$ et retardée de $6-10$ jours dans les tabacs KY 14 et MS KY $14 \times$ L8LC. Le sclaréol s'est montré très efficace à l'inhibition de la maladie causée par la race 0 sur les deux cultivars. Dans le tabac
MS KY $14 \times$ L8LC, l'infection par la race 1 a été inhibée tandis que dans le KY 14, l'infection a été réduite de $85 \%$ et réduite de 6 jours. Le labdénédiol a réduit la maladie de moitié sur les plantes de KY 14 de huit semaines. La phylloplanine de tabac a réduit la pathologie causée par les deux races de $50-60 \%$ et a retardé la maladie de $6-10$ jours. La phylloplanine a présenté moins d'effets suppresseurs sur les deux cultivars de tabac. Nous estimons que le sclaréol est le meilleur candidat à de futures recherches en raison de ses propriétés antifongiques et de sa disponibilité. Le cisabéniol, en dépit de sa bonne activité antifongique, n'est pas un candidat envisageable pour une utilisation à grande échelle en raison des limites de production et de stabilité. [Beitr. Tabakforsch. Int. 27 (2016) 113-125]

\section{INTRODUCTION}

Black shank is caused by the fungus Phytophthora parasitica var. nicotianae (PPN) that attacks roots and stems causing dark-brown to black lesions, and eventually killing the plant. Different tobacco varieties are affected differently by this fungus (1). A list of Burley and dark tobacco cultivars and their resistance/sensitivity to the fungus and other pathogens is published each year by cooperative efforts of the Universityof Kentucky, University of Tennessee, Virginia Tech University and North Carolina State University (2). Currently, black shank is found in the majority of tobacco fields in the Southern United States, causing damage to $2-5.5 \%$ of tobacco crops, but in some fields losses can be up to $100 \%(3,4)$. The losses for dark tobaccos in Kentucky and Tennessee are estimated to be 1.25 million dollars annually (5). Thus far, the most important approaches for controlling this devastating disease are: creation of resistant hybrids, fungicide treatment, crop rotation and biological control (6-9). Breeders have developed resistant Burley tobacco varieties such as KT 209LC, KT 206LC, MS KY $14 \times$ L8LC or MS Burley $21 \times$ L8LC (6). KT 209LC variety is highly resistant to both PPN-races (6). KY 14 variety is sensitive to both, race 0 and 1 of $P$. parasitica. KY $14 \times \mathrm{L} 8 \mathrm{LC}$ and the other L8 containing hybrid cultivars are resistant to race 0 . The resistance comes from the L8 parent which possesses a resistance gene from Nicotiana longiflora (10). This gene is fully dominant so that the F1 hybrids have the same resistance level as L8 itself. When L8 hybrids have been grown on soils infested with race 1, severe losses have been recorded (1). Resistant varieties can tolerate the disease to some extent in the absence of water deficiency. In 2012 there was much disease in Kentucky fields planted with resistant Burley varieties because of the prolonged dry weather and heat (11). Fungicide application is efficient in preventing the disease only in Burley varieties with resistance rating above 3 . However, fungicides are not efficient for highly susceptible Burley varieties or for dark tobaccos (1). In addition, fungicides may have long-term deleterious effects such as acquired resistance, collateral toxicity, and environmental pollution $(12,13)$. Because of the adverse effects of the fungicides, there is a need for alternative bio-chemicals, which are sustainable and ecofriendly. Plant-made products, such as sugar esters and terpenoids are shown to possess antibacterial, antifungal, 
and insecticidal properties (14-17). Essential oils, such as cinnamaldehyde (12) and tobacco root constituents such as chlorogenic acid and scopoletin, and also free phenolic acids (18) were found to be active against black shank disease. Our laboratory is specialized in studying surface chemistry of tobacco leaves. A tobacco phylloplanin (T-phylloplanin) was isolated from TI 1068, and characterized as a protein produced and secreted by tobacco short glandular trichomes. T-phylloplanin was found to be active against blue mold spores (19-21), and also to delay black shank infection of the roots of dark tobacco in a tube and a soil drench assay (22). cis-Abienol is a valuable natural product synthesized by glandular trichomes and secreted in the leaf gum in some tobaccos $(23,24)$. In TI 1068 it is produced by tall glandular trichomes. cis-Abienol has been reported to have antifungal, antimicrobial and antineoplastic properties $(25,22)$. KING (22) showed 2011 that in the dark tobacco variety NL Madole LC (susceptible to the disease) cis-abienol delayed the infection in a tube assay and prevented it in a soil drench assay. Results with cis-abienol and phylloplanin were preliminary, and concentration dependence was not done for either compound. Additional work was needed to determine if either or both of the natural products could be used to control black shank in greenhouse conditions.

Sclareol and labdenediol were also included in this study. Sclareol has a chemical structure close to cis-abienol. Sclareol is a natural compound found in Nicotiana glutinosa $(26,27)$ and Salvia sclare $(28)$. It possesses antimicrobial (29), anti-inflammatory (30), and antifungal activities (14, 25 ). The natural product labdenediol (found in tobacco, $N$. tomentosiformis, $N$. occidentalis, and $N$. petunia) was selected for testing because of its structural similarity to $\mathrm{cis}$ abienol and sclareol. It has been shown that labdenediol, isolated from the resin of Cistus creticus, possesses cytotoxic and antifungal activities $(31,32)$.

We hypothesized that treatment of tobaccos with cisabienol, T-phylloplanin, sclareol, and labdenediol could prevent/reduce disease symptoms. We assessed the inhibition of black shank in race 0 - and race 1-sensitive Burley tobacco, KY 14 and race $1-$ sensitive MS KY $14 \times$ L8LC in soil drench assay in the greenhouse. Seedlings were 7-8 week-old. In order to compare results from different treatments, plants were infected with standardized amount of spores that were introduced directly into the soil around the base of the stem after application of the natural compounds. Such an inoculation method imitates the natural zoospore infection through the root system.

\section{EXPERIMENTAL}

\section{Chemicals and plant material}

Sclareol and $\mathrm{N}, \mathrm{O}$-Bis(trimethylsilyl)trifluoroacetamide (BSTFA) were purchased from Sigma-Aldrich Co. LLC (St. Louis, MO, USA). Solvents were purchased from Thermo Fisher Scientific Inc. (Waltham, MA, USA).

KY 14 seeds were obtained from an in-house KTRDC collection, and MS KY $14 \times$ L8LC and KT 209LC seeds from Dr B. Pearce (Plant and Soil Science Department, University of Kentucky, USA). Seeds were grown in 6-inch pots in a growth chamber (14 hours light and 10 hours dark, at $22{ }^{\circ} \mathrm{C}$ and $23 \%$ relative humidity) for 20 days. Individual seedlings were transferred to 4 -inch pots and grown for another 15-35 days. Three days before the infection, the plantlets were transferred to the greenhouse in a designated area for the containment of the disease.

\section{Preparation of T-phylloplanin stock}

Tobacco plants (type TI 1068) were grown in the greenhouse for four months. More than 200 mature leaves were washed individually with water for $30 \mathrm{sec}$ to recover T-phylloplanin. The water solution was lyophylized, and T-phylloplanin was recovered as a powder. The weight of the concentrated phylloplanin was measured and dry aliquots were stored at $-20{ }^{\circ} \mathrm{C}$ until use. Quality analysis of the protein was performed using gel electrophoresis, as done previously (33). Phylloplanin bands were estimated to account for $8 \%$ of the lyophylized weight while salts accounted for $\sim 30 \%$ of it.

\section{Preparation of cis-abienol stock}

TI 1068 plants producing increased amount of $c i s$-abienol. Plants were grown to maturity in the greenhouse. 200 leaves were washed with acetonitrile for $30 \mathrm{sec}$ per leaf. The wash was concentrated via vacuum rotor evaporation to yield oily residue. The total amount of exudate collected was $6.3 \mathrm{~g}$. Aliquots were taken and derivatized to form trimethyl silyl esters (TMS) as described previously (34). An internal standard was added to each sample. The TMS derivatives were separated and analyzed by GC-MS (HP6890 GC equipped with HP5973 MS and automatic sampler injector), using $30.0 \mathrm{~m}$ Agilent capillary column $19091 \mathrm{~J}-413$ with $0.25 \mu \mathrm{m}$ film thickness and $0.25 \mathrm{~mm}$ diameter. Helium was the carrier gas with $1.8 \mathrm{~mL} / \mathrm{min}$ constant flow compensation, and injection temperature of $250{ }^{\circ} \mathrm{C}$. The oven program for running TMS ester derivatives was as follows: initial temperature: $180^{\circ} \mathrm{C}$ for $2.0 \mathrm{~min}$; rate: $8{ }^{\circ} \mathrm{C}$ per min until $280{ }^{\circ} \mathrm{C}$; hold: for $9.5 \mathrm{~min}$; total run time: $24.0 \mathrm{~min}$.

The cis-abienol ester on the chromatogram was identified according to the retention time and MS profile. cis-Abienol was evaluated to be $14 \%$ of the total extract. cis-Abienol was further purified by partitioning the crude extract between hexane and $80 \%$ methanol (23), and recovered in the hexane fraction. The purified extract was enriched in cis-abienol up to $85 \%$ (Figure 1). Hexane was evaporated and the chemical was stored in $95 \%$ ethanol at $4{ }^{\circ} \mathrm{C}$.

\section{Preparation of labdenediol stock}

Labdenediol is synthesized by glandular trichomes and secreted into the gum of non-commercial Nicotiana varieties, such as Red Russian and $N$. glutinosa var. 24A $(14,23,27)$. TI 1068 produces trace amounts of labdenediol. We have, however, generated a TI 1068 tobacco synthesizing a highly elevated level of labdenediol in the tobacco gum $(\sim 50 \%$ of total gum or $\sim 90 \%$ of total diterpenes). Plants of this tobacco were used to prepare the labdenediol stock. The procedure was essentially the same as for $c i s$-abienol, but without the purification step because labdenediol and sugar esters could not be easily separated. 


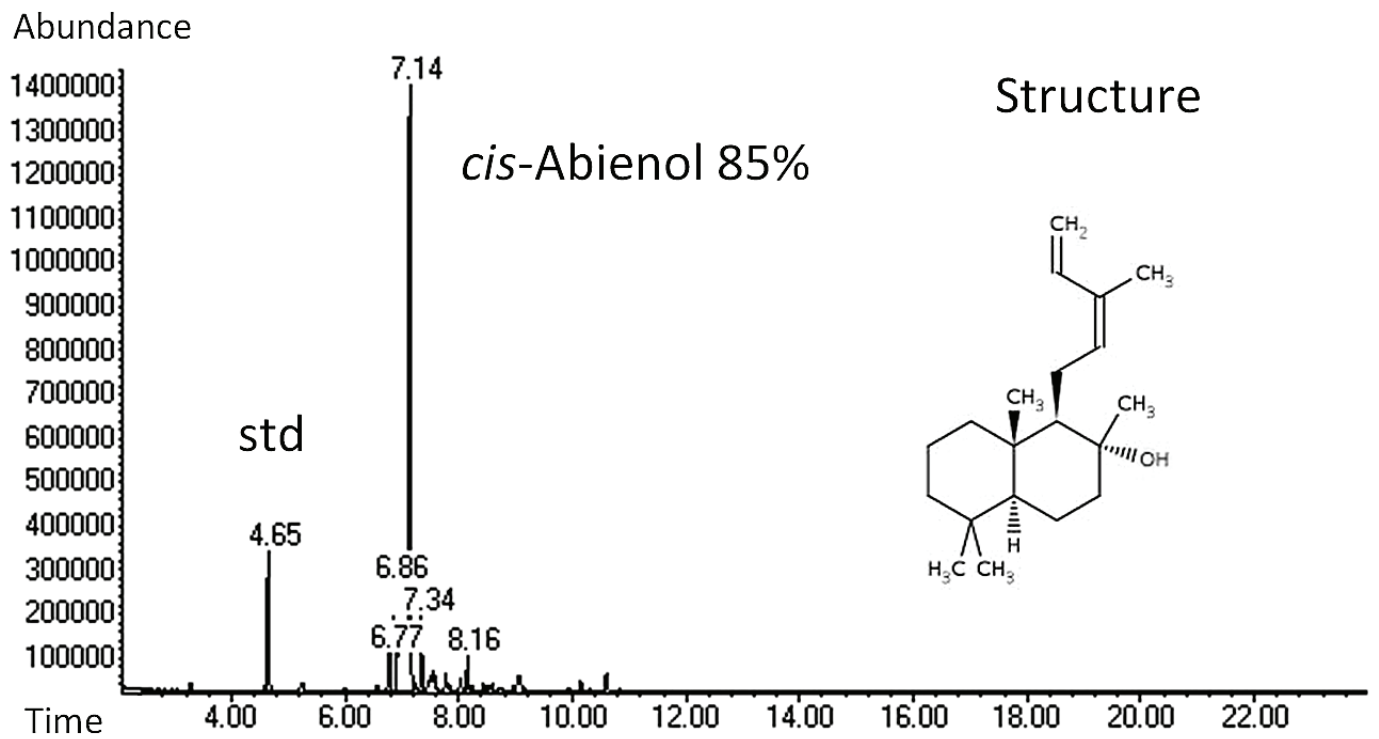

Figure 1. GC-MS chromatogram of purified cis-abienol. GC-MS analysis was performed using a $30.0 \mathrm{~m}$ Agilent capillary column (19091J413) with $0.25 \mu \mathrm{m}$ film thickness and $0.25 \mathrm{~mm}$ diameter. cis-Abienol was derivatized to TMS ester and identified according to the retention time and MS profile. The structure of cis-abienol is shown.

\section{Preparation of sclareol stock}

Most of the commercially-available sclareol is from cultivated clary sage. We purchased the sclareol, from Sigma-Aldrich Co. LLC (St. Louis, MO, USA) at 98\% purity. The powder was finely suspended in $100 \%$ methanol at a concentration $20-40 \mathrm{mg} / \mathrm{mL}$.

\section{Preparation of spores from P. parasitica fungus}

Race 1 isolate was obtained from Ed Dixon (Plant Pathology, UK, Lexington, KY) and race 0 isolate from N. Martinez (KTRDC, UK, Lexington, KY). We prepared long-term storage mycelia plugs $\left(\sim 1 \mathrm{~cm}^{3}\right.$ of agar, containing mycelia) in water, and stored them in dark, at room temperature (35, modified by N. Martinez, personal communication). The stored mycelia were starters for fresh cultures on a basal V8 medium, containing buffered V8 tomato juice (35). The plates were kept in the dark for 8 days. Five plugs $\left(\sim 1 \mathrm{~cm}^{3}\right)$ of agar-mycelia were cut from the edge of the mycelium mat, and partially dipped in sterile water, in the dark, at room temperature for 7-14 days. Mycelia were daily monitored under scope for formation of sporangia which appeared as yellow balls at the end of hyphae. This is an indication of successful zoospore formation. Usually, sporangia were visible in 7-10 days. Zoospores were released from the sporangia after $30 \mathrm{~min}$ cold shock $\left(4^{\circ} \mathrm{C}\right)$, followed by incubation at $37^{\circ} \mathrm{C}$ for $30 \mathrm{~min}$. Moving spores were monitored under microscope. Small aliquots of suspension were treated with sodium azide in order to immobilize them and determine the concentration using hemocytometer. For both, race 1 and race 0 , the harvest was from $50,000-100,000$ spores per $\mathrm{mL}$. They were further diluted with sterile water to reach desired concentrations.

Treatment with spores, T-phylloplanin, cis-abienol, sclareol, labdenediol and methanol

All the treatments were applied on uniformly grown plants prior to infection. $1 \mathrm{~mL}$ of designated chemical per plant was applied around the base of plant stem on the soil level. Phylloplanin was applied as water solution, and cis-abienol, sclareol, and labdenediol were applied as methanol solutions. T-phylloplanin concentration was $100 \mathrm{mg} / \mathrm{mL}$; cisabienol concentration: $20 \mathrm{mg} / \mathrm{mL}$; sclareol: $40 \mathrm{mg} / \mathrm{mL}$, and labdenediol: $40 \mathrm{mg} / \mathrm{mL}$. Within 10 min of treatments, $1 \mathrm{~mL}$ of spore suspension $\left(30-33 \times 10^{3}\right.$ per $\mathrm{mL}$ of water) was applied around the base of each seedling. The 'spore' treatment included only spore application. Disease development was observed 6-13 days post treatment. The monitored infection symptoms included wilting and yellowing of the leaves, and development of a black stem at the base of the plant. Each treatment, including spores alone, was applied on at least three plants, and was repeated three to five times. In the graphs data are presented as average values with error bars. Treatments were done similarly with both race 0 and race 1 spores. Methanol was tested in advance for toxicity to the plants and spores. Methanol treatment was executed the same way as the chemical treatments. When methanol toxicity to the plants was tested, it was applied alone. When the toxicity to the spores was tested, it was applied before spores, as described for the chemical treatments. 


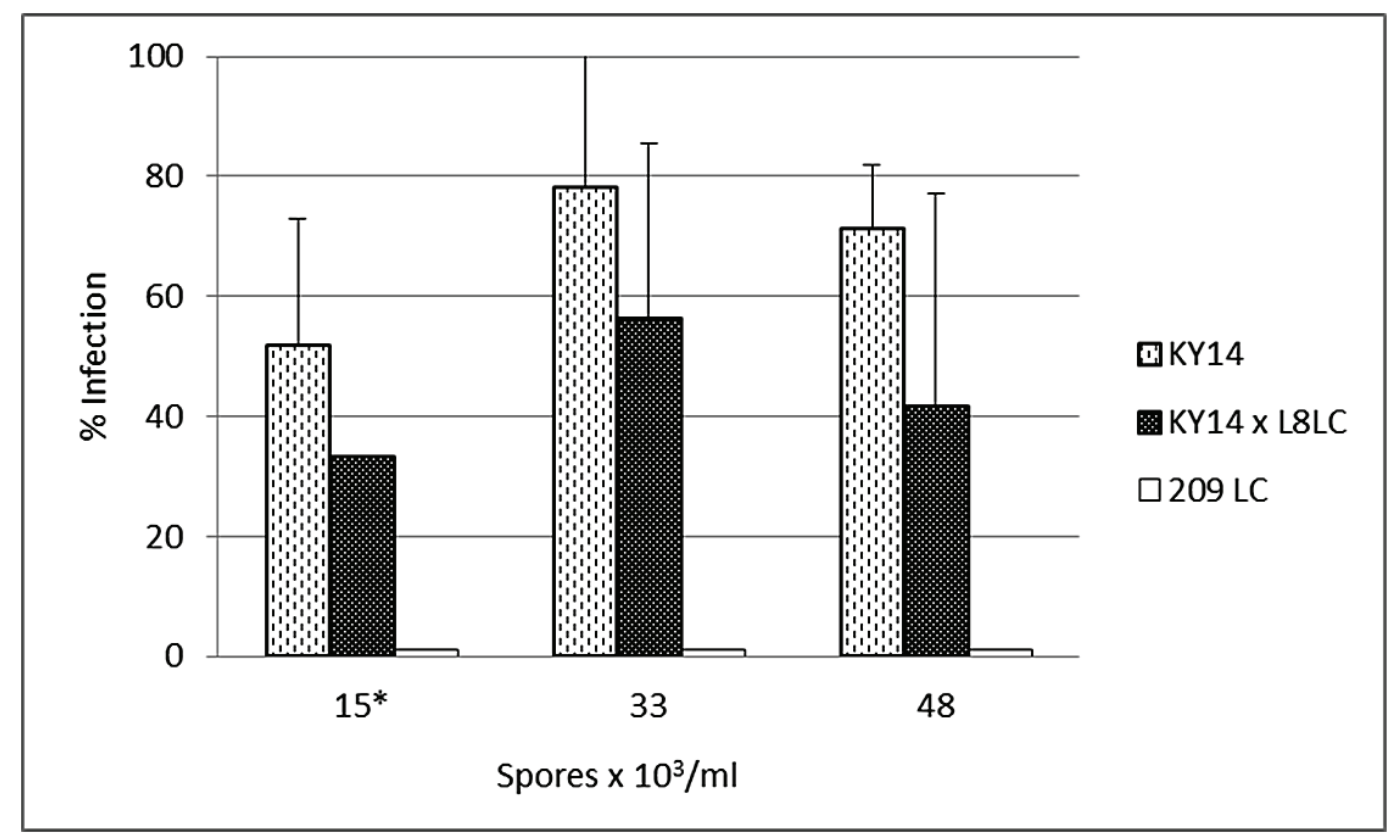

Figure 2. Infection of KY 14, MS KY $14 \times$ L8LC, and KT 209LC as a function of spore concentration. The three treatments represent different spore concentrations. Each treatment was applied on three to five plants, and repeated four to seven times. ${ }^{*}$ For each treatment, the spore concentration varied between repeats by $\pm 2 \times 10^{3}$ per $\mathrm{mL}$. The numbers on the X-axis represent average spore concentration. Spores were from race 1 and plants were 35 day-old. Cultivar KT 209LC is resistant to $P$. nicotianae race 0 and 1 infection, and was included as a negative control.

\section{RESULTS}

Selection of working concentrations for spores, phylloplanin, cis-abienol, sclareol and labdenediol

\section{- Spores}

Concentrations of 15,33 , and $48\left(\times 10^{3}\right)$ spores per $\mathrm{mL}$ of race 1 were tested (Figure 2 ). The average percent infection for the three concentrations was different, but the standard deviations were overlapping. We did not observe a strong correlation between spore concentration and percent infection. The hybrid cultivar MS KY $14 \times$ L8LC was less prone to infection than KY 14 using the same spore concentrations. The concentration of $33 \times 10^{3}$ spores per $\mathrm{mL}$ appeared to give better average infection rate than $15 \times 10^{3}$ per $\mathrm{mL}$ and $48 \times 10^{3}$ spores per $\mathrm{mL}$ (Figure 2 ), and was selected to be the working concentration for both races in all tobacco cultivars. KT 209LC is a black shank resistant (2), and was used in this experiment as a negative control. The dark tobacco NL Madole LC was reported to acquire root infection after exposure to $1 \times 10^{3}$ spores per $\mathrm{mL}(22)$. This particular cultivar appears to be very sensitive to the disease; the survival rate in heavily infected soils is only about $3 \%$ (36).

\section{- Phylloplanin}

Phylloplanin was tested against race 1 spore caused disease in 5-6 week-old KY 14 plants with concentrations from $37-150 \mathrm{mg} / \mathrm{mL}$. Concentrations of $75 \mathrm{mg} / \mathrm{mL}$ or less did not prevent infection but $100 \mathrm{mg} / \mathrm{mL}$ and above appeared to reduce the disease by 30 to $60 \%$ (Figure $3 a$ ). We selected concentration of $100 \mathrm{mg} / \mathrm{mL}$ for our subsequent experiments. Similar concentration was applied previously to dark tobacco NL Madole LC, and onset of root infection was delayed by 8 days in a float tube assay (22). Phylloplanin was more potent against Perenospora tabacina. Protein concentration of $100 \mu \mathrm{g} / \mu \mathrm{L}$ inhibited spore germination in vitro, and $200 \mathrm{ng}$ protein inhibited blue mold infection on tobacco leaf assays (33).

\section{- cis-Abienol}

Five week-old KY 14, KY $14 \times$ L8 and KT 209LC plants were initially treated with 2 and $6 \mathrm{mg}$ cis-abienol per $\mathrm{mL}$ of $95 \%$ ethanol. cis-Abienol is completely soluble in ethanol, and partially in other organic solvents, but not in water. Treated plants, including the resistant KT 209LC, were not infected, but died from leaf bleaching and stem necrosis. According to KING (22) ethanol was not harmful to dark tobacco NL Madole LC. A series of water diluted ethanol was prepared and toxicity was tested in the absence of spores. Ethanol concentrations of $25 \%$ or less were not toxic to the seedlings. However, at these dilutions cisabienol precipitated and could not be used for plant treatment.

In order to achieve cis-abienol solubilization without the suspension being toxic to the plants, we tested the organic solvents methanol, ethyl acetate, ethyl lactate, and butyl butyrate. Methanol did not damage 5-8 week-old plants. Ethyl lactate treatment of small-size plants showed symptoms similar to black shank, such as wilting, yellowing of the leaves, and stem damage. Ethyl acetate and butyl butyrate were also toxic to the plants. Methanol alone was 

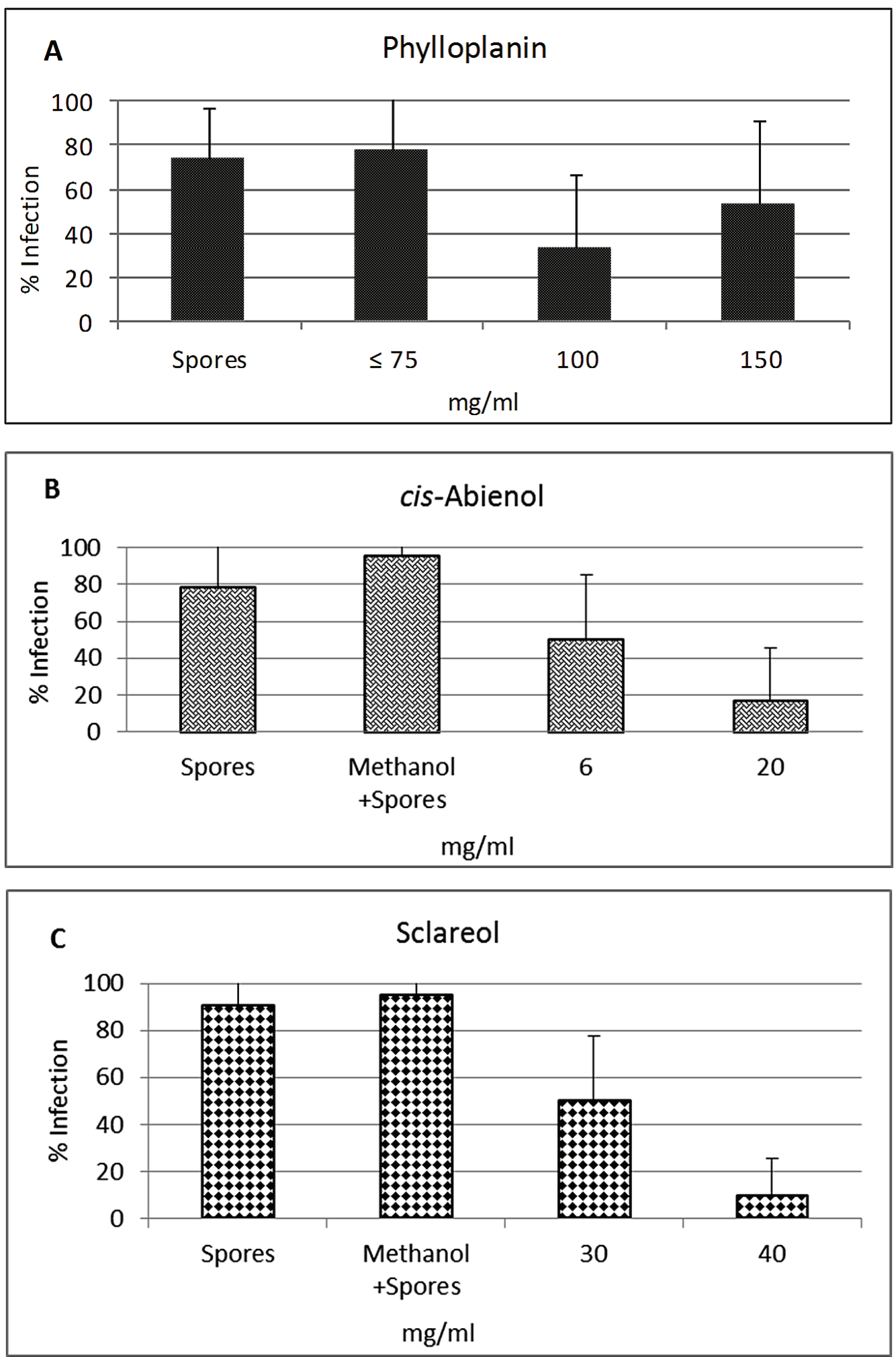

Figure 3. Establishing working concentrations of phylloplanin, cis-abienol and sclareol for the suppression of black shank in KY 14 plants. The 'spore' treatment (Fig. 3A, 3B, and 3C) refers to race 1 spore application ( $33 \times 10^{3}$ spores per plant) only. The other treatments included consecutive application of chemicals and spores. 3A: Phylloplanin application includes four treatments: spores only and three concentrations of phylloplanin; 3B: cis-Abienol application includes four treatments: spores only, methanol treatment, and two concentrations of cis-abienol; 3C: Sclareol application includes four treatments: spores only, methanol treatment, and two concentrations of sclareol. cisAbienol and sclareol were dissolved in methanol. Methanol was not harmful to the spores using the technique for spore and chemical application described in the Experimental section. Each treatment was applied on at least three plants, and was repeated three to six times. Column values represent the average and the bars represent the standard deviation. Plants were 5-week old and results were recorded 13 days post-infection. 
tested for toxicity to the zoospores. In Figure $3 \mathrm{~B}$ and $3 \mathrm{C}$ the second treatment represents application of pure methanol ( $1 \mathrm{~mL}$ ), followed by spore application. Results show that $\sim 100 \%$ of methanol-treated plants were infected indicating that using the described treatment technique methanol is not harmful to the spores. We can assume that cis-abienol, sclareol, and labdenediol inhibition of the black shank infection is due to the substances, not due to the methanol in which they are dissolved. cis-Abienol formed a fine suspension in methanol that was applied evenly as a drench. Treatment of KY 14 plants with $20 \mathrm{mg} / \mathrm{mL}$ cisabienol in methanol suppressed the diseases more than $80 \%$ (Figure 3B). This concentration was used in the further experiments.

\section{- Sclareol and labdenediol}

Sclareol crystals and labdenediol extract solubilized well in methanol. Sclareol formed a fine suspension, while labdenediol was completely dissolved. Sclareol caused 50\% disease inhibition at concentration of $30 \mathrm{mg} / \mathrm{mL}$, but was very effective at $40 \mathrm{mg} / \mathrm{mL}$. (Figure 3C). Labdenediol was more suppressive to the disease at concentration of $30 \mathrm{mg} / \mathrm{mL}$ than $20 \mathrm{mg} / \mathrm{mL}$ (not shown). Sclareol was further applied at $40 \mathrm{mg} / \mathrm{mL}$, and labdenediol at $30 \mathrm{mg} / \mathrm{mL}$, respectively.

\section{Effect of phylloplanin, cis-abienol, and sclareol treatments on black shank infection of younger KY 14 and MS KY $14 \times$ L8LC plants}

Experiments were performed on 7 week-old, 6 inch tall plants having 5-6 leaves. Before spore application, plants were treated with phylloplanin, sclareol, or cis-abienol by soil drenching technique. We used optimized concentrations as follows: for phylloplanin: $100 \mathrm{mg} / \mathrm{mL}$; cis-abienol: $20 \mathrm{mg} / \mathrm{mL}$, and sclareol: $40 \mathrm{mg} / \mathrm{mL}$. The disease development was monitored at 6 th, 10 th and 13 th day post-infection. Wilting was a first indication of infection and very often was noticeable 3 days after addition of spores. However, yellowing was not a reliable criterion for the disease because often plants died rapidly without showing this symptom. The three bio-chemicals suppressed or inhibited the disease, caused by both race 0 and race 1 spores. cis-Abienol and sclareol inhibited race 0 disease completely and suppressed race 1 disease by $80 \%$ (Figure 4A, 4B). These also caused a delay of the disease symptoms. In race 1 experiments, sclareol and cis-abienol delayed symptoms by 6 days (Figure 4C). On the 10th day post-inoculation there was only $15 \%$ infection, while in the control the infection was $80 \%$. Phylloplanin suppressed disease development from both races by $50 \%$ (Figure $4 \mathrm{~A}$ ). In race 0 and race 1 experiment only $15-20 \%$ of phylloplanin-treated plants were infected on the 6th day ( $v s .80 \%$ in the control), and $40-55 \%$ were infected on the 13th day (vs. $80 \%$ control) (Figure 4B, 4C).

As expected, the hybrid KY14 $\times$ L8LC was not affected by race 0 infection (Figure 5A). Sclareol and cis-abienol inhibited race 1 infection of MS KY14 $\times$ L8LC seedlings completely. No disease signs were observed up to the 13th day. Phylloplanin-treated plants were infected $18 \%$ (vs. $65 \%$ in the control). In addition to the reduced infection, phylloplanin delayed it by 10 days (Figure 5B and 5C).
Effect of phylloplanin, labdenediol, and sclareol treatments on black shank infection of older KY14 and MS KY14 × L8LC plants

An independent set of experiments was conducted with older, 8 week-old seedlings to observe if the age will impact disease suppression after different treatments. Plants were about 8 inch-tall and had 8-9 leaves. Plants were treated with phylloplanin $(100 \mathrm{mg} / \mathrm{mL})$, sclareol $(40 \mathrm{mg} / \mathrm{mL})$ and labdenediol $(30 \mathrm{mg} / \mathrm{mL})$ (Figure 6). The three chemicals partially suppressed the disease caused by both races. $30 \%$ of the labdenediol-treated plants were infected ( $v s .80 \%$ infected controls) with the zoospores of both races (Figure 6A). Sclareol and phylloplanin were more efficient against race 1 infection $(20 \%$ and $30 \%$, respectively) than against race 0 infection ( $45 \%$ and $55 \%$, respectively) (Figure 6A). The three compounds also caused a delay of the disease symptoms. Sclareol delayed the race 1 -caused disease by 10 days, and phylloplanin by 6 days, respectively. The labdenediol preparation caused partial suppression of the disease. Only $20 \%$ of labdenediol treated plants were infected by the zoospores of both races on the 6th day, and $35 \%$ on the 10th day ( $v s .80 \%$ in controls) (Figure 6B and 6C).

Labdenediol, sclareol and phylloplanin did not suppress race 1 -caused disease in 8 week-old MS KY14 $\times$ L8LC plants (Figure 7A). However, sclareol delayed infection by 6 days, while labdenediol caused a reduced infection rate of $15 \%$ six days after spore application (Figure 7B).

\section{DISCUSSION}

The objective of the current work was to test the potential of sclareol, cis-abienol, phylloplanin, and labdenediol against black shank infection. These chemicals have previously shown antifungal, insecticidal, and antibacterial properties $(14,19,20,22,29,37,38)$ but have not been studied for black shank prevention. There are preliminary indications that $c i s$-abienol and phylloplanin have a potential against black shank in laboratory conditions (22).

In order to standardize spore application and to be able to compare infection/suppression of the disease from different experiments, we developed a method for pure zoospore preparation and for utilizing relatively uniform spore concentration. Zoospores were applied to the soil surface around the stem base to imitate the natural process of infection. There is limited literature regarding $P$. parasitica spore preparation and plant infection in the laboratory or greenhouse. Methods vary depending on the planned experiments and include free chlamydospores, or hyphal mat applied to the stem wounds, or infected oat grains and leaf discs (39-42). The method for spore preparation used here is very simple and inexpensive but requires individual application of spores to each potted plant in the greenhouse. In the current experiments cis-abienol and sclareol strongly suppressed and/or delayed the development of black shank disease in 7 week-old susceptible Burley cultivars. The results suggest inhibition of zoospore germination or penetration into the plant roots. This suggestion is supported by some other works that demonstrated direct impact of sclareol/episclareol and labdenediol on the sporangia 


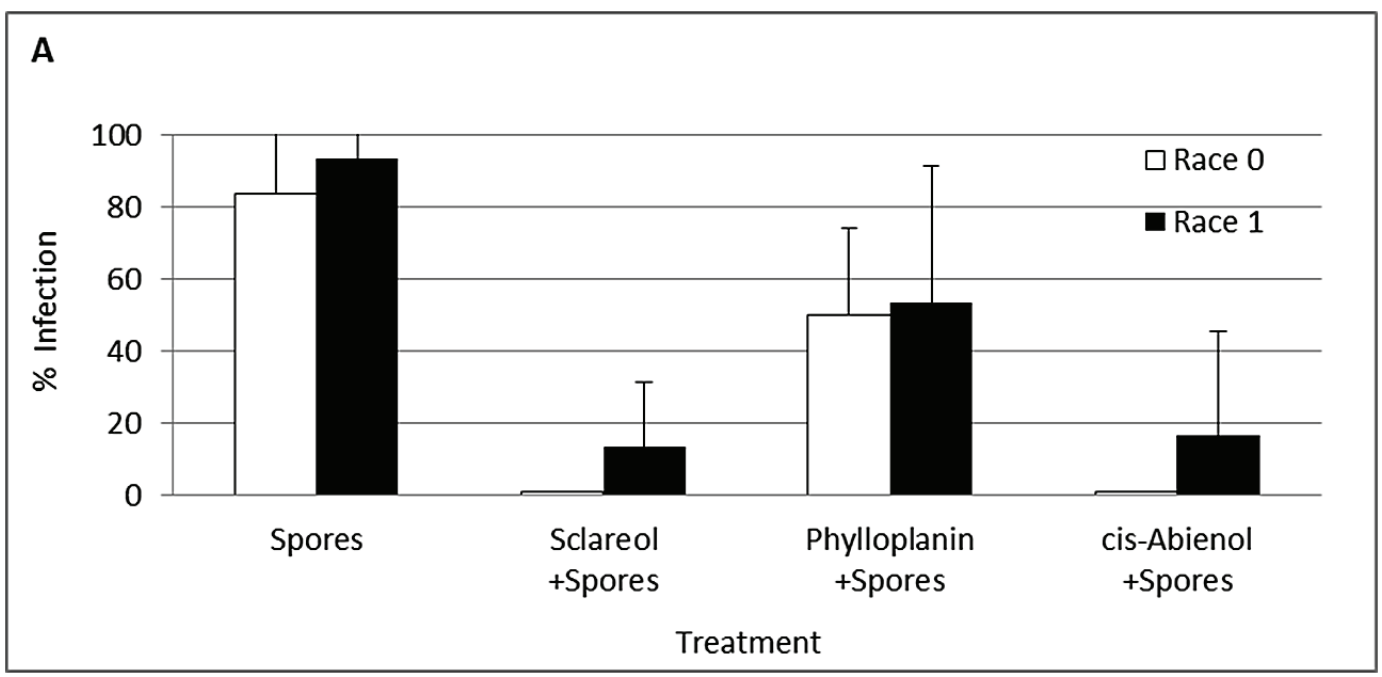

B

Race 0 Disease Development

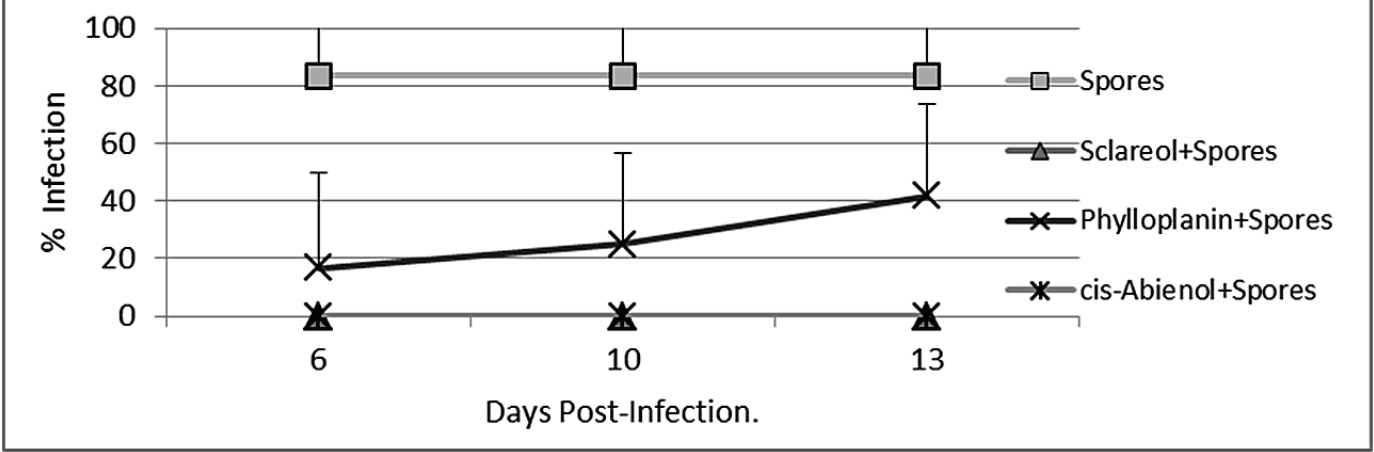

C

Race 1 Disease Development

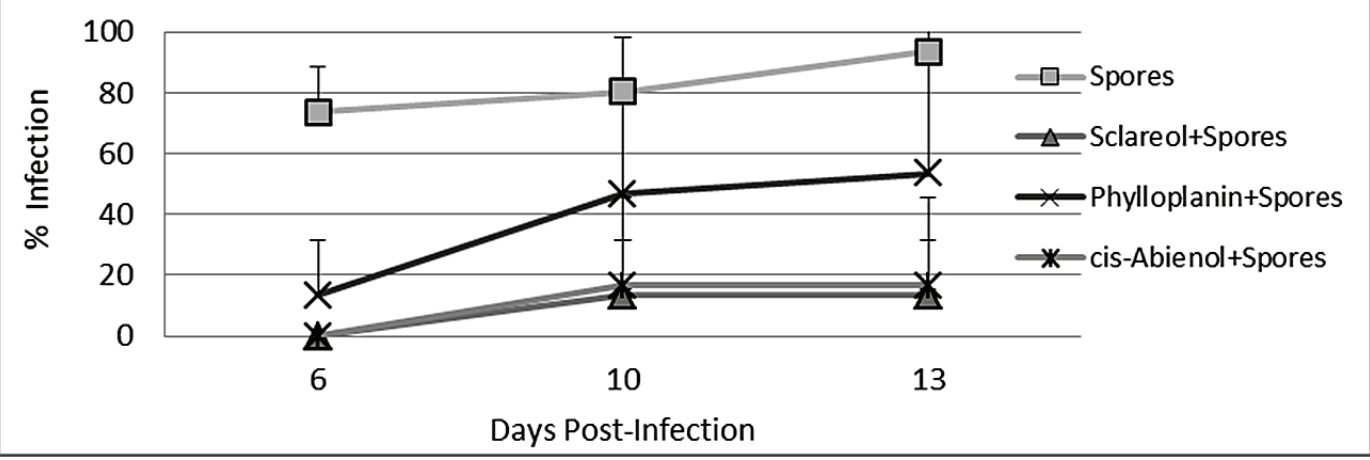

Figure 4. Effect of sclareol, phylloplanin, and cis-abienol on the suppression of black shank disease in younger KY 14 plants. The 'spore' treatment (Figure 4A, 4B, and 4C) refers to spore application only. The other treatments included consecutive application of chemicals and spores. Each plant received $\sim 33 \times 10^{3}$ spores (from either race). In addition, each treated plant received either $40 \mathrm{mg}$ sclareol, $100 \mathrm{mg}$ phylloplanin, or $20 \mathrm{mg}$ cis-abienol. cis-Abienol and sclareol were dissolved in methanol. Methanol was not harmful to the spores, as shown in Figure 3B and $3 \mathrm{C}$. Each treatment was applied on three plants, and was repeated three to five times. 4A: Summary of the black shank suppression response 13 days post-infection. Column values represent the average and the bars standard deviation; 4B and 4C: The disease development was monitored 6,10 , and 13 days post-infection. 

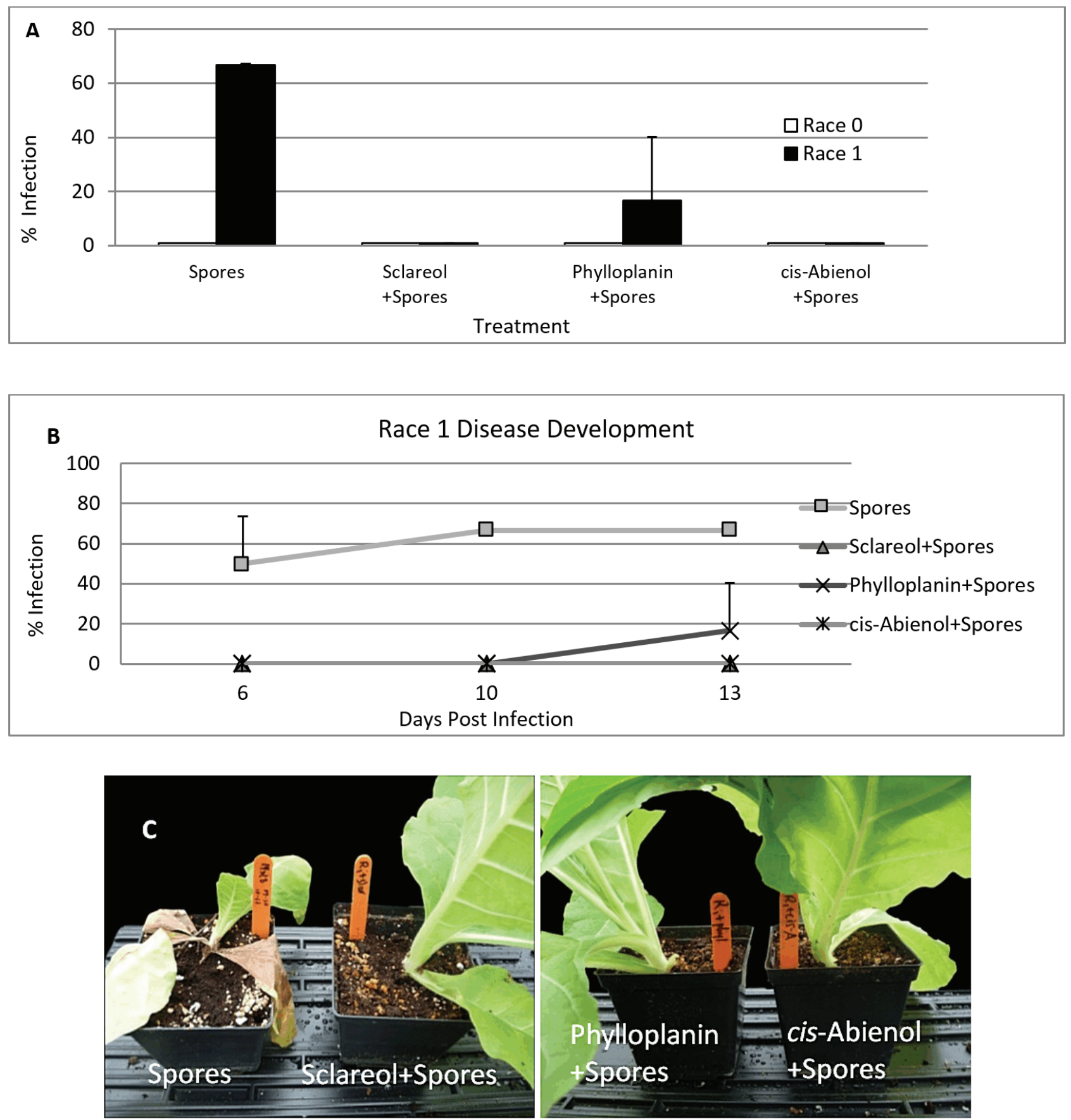

Figure 5. Effect of sclareol, phylloplanin and cis-abienol on suppression of black shank disease in 7 week-old MS KY $14 \times$ KT L8LC plants. This hybrid is resistant to race 0 caused disease. The 'spore' treatment refers to spore application only. The other treatments included consecutive application of chemicals and spores. Each plant received $\sim 33 \times 10^{3}$ spores (from either race). In addition, each treated plant received either $40 \mathrm{mg}$ sclareol, $100 \mathrm{mg}$ phylloplanin, or $20 \mathrm{mg}$ cis-abienol. cis-Abienol and sclareol were dissolved in methanol. Methanol was not harmful to the spores, as shown in Figure 3B and 3C. Each treatment was applied on at least three plants, and repeated three to five times (5A and 5B). 5A: Summary of the black shank suppression response 13 days post-infection. Column values represent the average and the bars represent the standard deviation; 5B: The disease development was monitored 6, 10, and 13 days post-infection; 5C: Greenhouse monitoring of black shank symptoms 10 days post-infection. Phylloplanin delayed the symptoms by 10 days, and sclareol and cis-abienol inhibited the disease. 

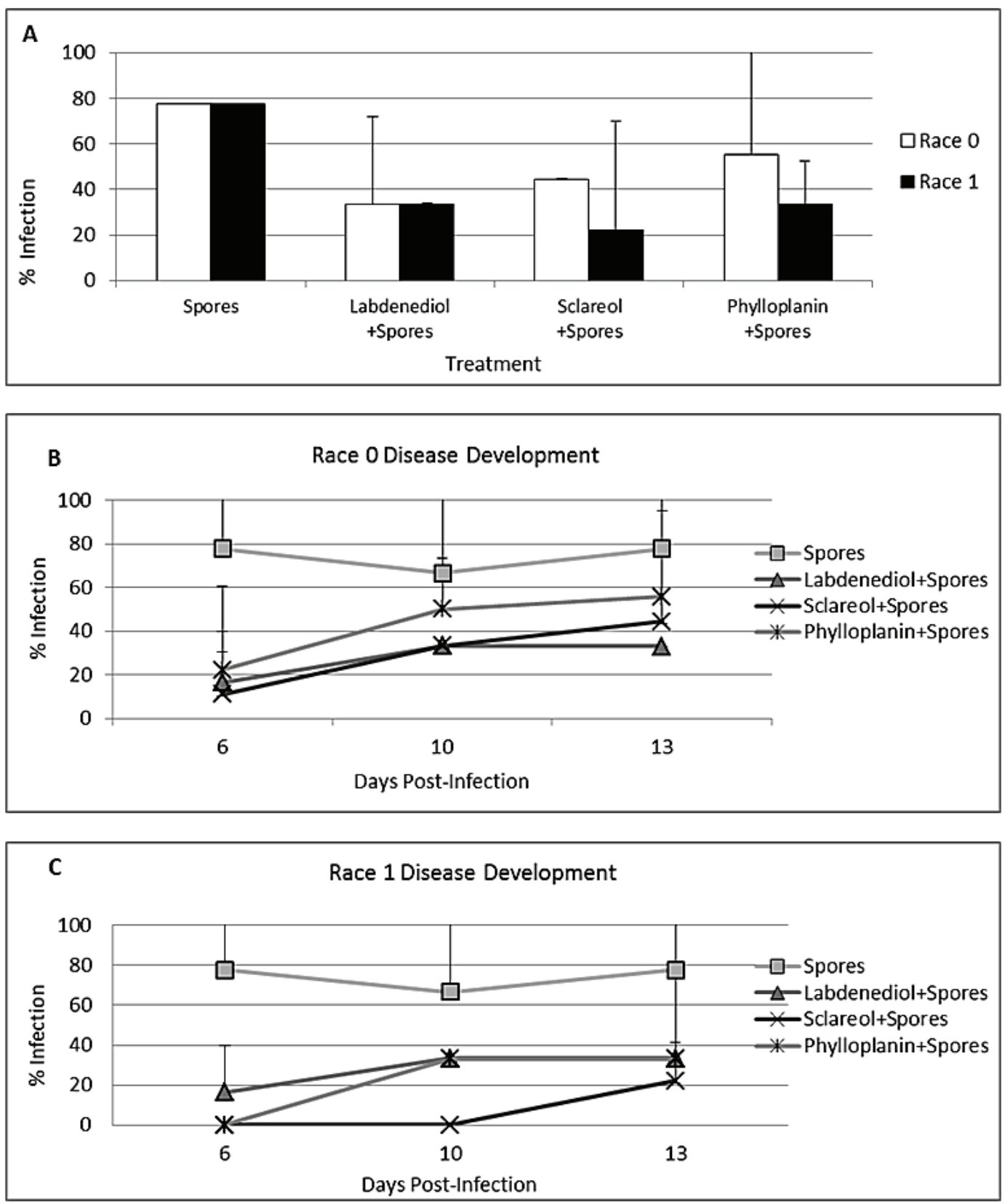

Figure 6. Effect of labdenediol, sclareol, and phylloplanin on suppression of black shank disease in 8 week-old KY14 plants. The 'spore' treatment (Figure 6A, 6B, and 6C) refers to spore application only. The other treatments included consecutive application of chemicals and spores. Each plant received $\sim 33 \times 10^{3}$ spores (from either race). In addition, each treated plant received either $30 \mathrm{mg}$ labdenediol, $40 \mathrm{mg}$ sclareol, or $100 \mathrm{mg}$ phylloplanin. Sclareol and labdenediol were dissolved in methanol. Methanol was not harmful to the spores, as shown in Figure 3B and 3C. Each treatment was applied on three plants, and was repeated three to five times. The technique for spore and chemical application is described in the Experimental section; 7A: Results are recorded 13 days post-infection. Column values represent the average and the bars represent the standard deviation; $6 \mathrm{~B}$ and $6 \mathrm{C}$ : The disease development was monitored 6,10 , and 13 days post-infection.

formation and mycelium growth. BAILEY et al. (14) found (1974) that sclareol/epi-sclareol from $N$. glutinosa directly inhibited the radial extension of mycelium from 16 fungal species growing on agar. Sclareol and labdenediol were shown to inhibit $P$. tabacina sporangia germination (43). cis-Abienol and sclareol treatments suppressed strongly both races 0 - and 1-caused disease in MS KY 14 plants. This result implies that e.g., sclareol will have efficient disease suppression when applied to a mix of both races, and it will also be efficient for treatment of other Burley cultivars with no black shank resistance. This paper is the first to show that sclareol suppresses black shank disease in tobacco. Phylloplanin showed less potential against black shank comparatively to sclareol and cis-abienol, reducing by half the plant infection caused by both races.

Phylloplanin, sclareol, and labdenediol treatments were less effective with older KY14 plants and not effective against race 1 -caused disease in older MS KY $14 \times$ L8LC plants (Figure 7A). The relationship between treatment effect and plant age is inconclusive. In the field, plants can be infected 

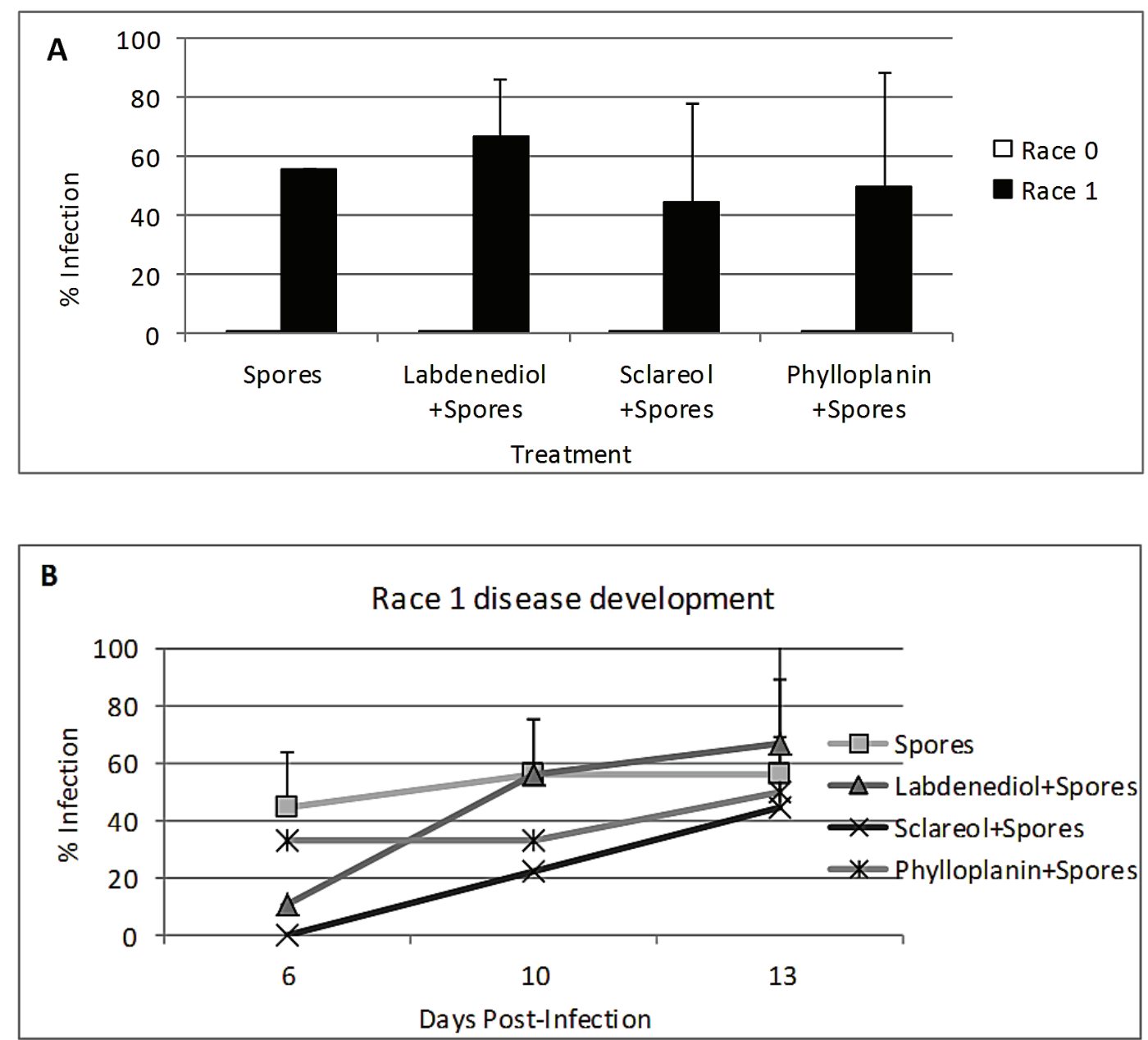

Figure 7. Effect of labdenediol, sclareol, and phylloplanin on suppression of black shank disease in 8 week-old MS KY $14 \times$ KT L8LC plants. This hybrid is resistant to race 0-caused disease. The 'spore' treatment (Figure 7A, 7B) refers to spore application only. The other treatments included consecutive application of chemicals and spores. Each plant received $\sim 30 \times 10^{3}$ spores (from either race). In addition, each treated plant received either $30 \mathrm{mg}$ labdenediol, $40 \mathrm{mg}$ sclareol, or $100 \mathrm{mg}$ phylloplanin. Sclareol and labdenediol were dissolved in methanol. Methanol was not harmful to the spores, as shown in Figure 3B and 3C. Each treatment was applied on at least three plants, and was repeated three to five times. The technique for spore and chemical application is described in the Experimental section. 7A: Results are recorded 13 days post-infection. Column values represent the average and the bars represent the standard deviation; 7B: The disease development was monitored 6, 10, and 13 days post-infection.

at any stage of development. We expected no difference in the resistance response due to age but observed that treated younger plants were less infected. Additional work is needed to clarify the relationship between plant treatments, plant age, and plant susceptibility to the disease.Sclareol appears to be the best candidate for future studies on a larger scale due to its good potential to suppress the disease caused by both $P$. parasitica var. nicotianae races in the studied Burley cultivars. Sclareol is commercially produced from clary sage (Salvia sclarea) and is easy to acquire. cis-Abienol was as effective as sclareol in preventing black shank disease. However, collecting cisabienol requires much time and effort. In addition, cisabienol is easily modified and decomposed by oxidation (44). These disadvantages make it unsuitable for additional studies with field-grown plants. Labdenediol worked well in suppressing the disease in younger KY14 plants. Further studies are needed, however, with a well-purified substance.

\section{ACKNOWLEDGMENTS}

We thank the Council for Burley Tobacco Inc. (Lexington, KY, USA) for financial support. We are grateful to Dr. Natalia Martinez (KTRDC, Lexington, KY, USA) for race 0 isolate and valuable advice regarding spore maintenance. We thank Mr. Ed Dixon (Plant Pathology, University of Kentucky, Lexington, KY, USA) for supplying race 1 isolate, and Dr. Kenny Seebold (Plant Pathology, University of Kentucky, Lexington, KY, USA) for consultations regarding the disease. We thank Dr. Alain 
Chautems (Geneva Botanical Garden, Geneva, Switzerland) for the help with the French translation of the abstract.

\section{REFERENCES}

1. Bost, S. and D. Hensley: Plant Diseases - Black Shank of Tobacco, 2010; University of Tennessee, Institute of Agriculture, USA. Available at: https://utextension. tennessee.edu/washington/Documents/black_shank.pdf (Accessed June 30, 2016).

2. Pearce, B., B. Miller, E. Walker, M. Vann, and S. Whitley: Selecting Burley Tobacco Varieties; in: 2015-2016 Burley and Dark Tobacco Production Guide, edited by B. Pearce, 2015, pp. 3-10. Available at: https://tobacco.ces.ncsu.edu/wp-content/uploads/ 2015/04/2015-2016-Burley-Production-Guide.pdf ?fwd $=$ no (Accessed June 30, 2016).

3. Nesmith, W.: Effect of black shank on yield of burley tobacco; UK Cooperative Extension Service, 1994. Available at: http://www.uky.edu/Ag/IPM/ppfacts/ ppfsagt3.htm (Accessed July 22, 2016).

4. Gallup, C.A., M.J. Sullivan, and H.D. Shew: Black Shank of Tobacco - The Plant Health Instructor; 2006. Available at: http:/www.apsnet.org/edcenter/intropp/ lessons/fungi/Oomycetes/Pages/BlackShank.aspx (Accessed June 30, 2016). DOI: 10.1094/PHI-I-20060717-01

5. Bailey, W.A.: Evaluation of Variety Resistance and Fungicides for Control of Black Shank (Phytophthora nicotianae) in Dark Tobacco; CORESTA 2009 Meeting, Rovinj, Croatia, 2009, AP07. Available at: https:/www.coresta.org/abstracts/evaluation-varietyresistance-and-fungicides-control-black-shankphytophthora-nicotianae (Accessed June 30, 2016).

6. Pearce, B., P. Denton, A. Bailey, and B. Miller: Selecting Burley Tobacco Varieties; in: 2013-2014 Kentucky \& Tennessee Tobacco Production Guide; University of Kentucky UKnowledge, Agricultural and Natural Resources Publications, 2013, pp. 5-8. Available at: http://uknowledge.uky.edu/cgi/viewcontent.cgi?articl $\mathrm{e}=1073 \&$ context $=$ anr_reports (Accessed June 30, 2016).

7. Cartwright, K.D. and H.W. Spurr Jr: Biological Control of Phytophthora parasitica var. nicotianae on Tobacco Seedlings with Non-Pathogenic Binucleate Rhizoctonia Fungi; Soil Biol. Biochem. 30 (1998) 1879-1884. DOI:10.1016/S0038-0717(98)00019-4

8. Ren, X., N. Zhang, M. Cao, K. Wu, Q. Shen, and Q. Huang: Biological Control of Tobacco Black Shank and Colonization of Tobacco Roots by a Paenibacillus polymyxa Strain C5; Biol. Fertil. Soils 48 (2012) 613-620. DOI: 10.1007/s00374-011-0651-4

9. Blagoeva-Nikolaeva, V., S. Slavov, and L. Varsano: Possibilities for Biological Control of Black Shank Disease in Tobacco with Bacillus cereus; Biotechnology \& Biotechnological Equipment 9 (1995) 36-39. DOI: $10.1080 / 13102818.1995 .10818819$

10. Valleau, W.D., G.W. Stokes, and E.M. Johnson: Nine Years' Experience with the Nicotiana longiflora Factor for Resistance to Phytophthora parasitica var. nicotianae in the Control of Black Shank; Tob. Sci. 4 (1960) 92-94.

11. Seebold, K.: Hot, Dry Weather Exacerbating Black Shank; UKAgNews, 2012. Available at: http://news.ca.uky.edu/article/hot-dry-weatherexacerbating-black-shank (Accessed June 30, 2016).

12. Lu, M., Z. Han, and L. Yao: In Vitro and In Vivo Antimicrobial Efficacy of Essential Oils and Individual Compounds Against Phytophthora parasitica var. nicotianae; J. Appl. Microbiol. 115 (2013) 187-189. DOI: $10.1111 /$ jam. 12208

13. Monkiedje, A. and M. Spiteller: Degradation of Metalaxyl and Mefenoxam and Effects on the Microbiological Properties of Tropical and Temperate Soil; Int. J. Environ. Res. Public Health 2 (2005) 272-285.

14. Bailey, J.A., G.G. Vincent, and R.S. Burden: Diterpenes from Nicotiana glutinosa and their Effect on Fungal Growth; J. Gen. Microbiol. 85 (1974) 57-64. DOI: 10.1099/00221287-85-1-57

15. Chortyk, O.T., R.F. Severson, H.C. Cutler, and V.A. Sisson: Antibiotic Activities of Sugar Esters Isolated from Selected Nicotiana Species; Biosci. Biotechnol. Biochem. 57 (1993) 1355-1356. DOI: 10.1271/ bbb. 57.1355

16. Puterka, G.J., W. Farone, T. Palmer, and A. Barrington: Structure-Function Relationships Affecting the Insecticidal and Miticidal Activity of Sugar Esters; J. Econ. Entomol. 96 (2003) 636-644. DOI:10.1093/jee/96.3.6 36

17. Wang, E., R. Wang, J. DeParasis, J.H. Loughrin, S. Gan, and G.J. Wagner: Suppression of a P450 Hydroxylase Gene in Plant Trichome Glands Enhances NaturalProduct-Based Aphid Resistance; Nat. Biotech. 19 (2001) 371-374. DOI: 10.1038/86770

18. Snook, M.E., O.T. Chortyk, and A.S. Csinos: Black Shank Disease Fungus Inhibition of Growth by Tobacco Root Constituents and Related Compounds; in: Naturally Occurring Pest Bioregulators; edited by P.A. Hedin, ACS Symposium Series, Washington DC, USA, Vol. 449, 2009, pp. 388-398. Available at: http://agris.fao.org/agris-search/search.do?recordID =US9145698 (Accessed June 30, 2016). DOI: 10.1021/ bk-1991- 0449.ch027

19. Shepherd, R.W., W.T. Bass, R.L. Houtz, and G.J. Wagner: Phylloplanins of Tobacco are Defensive Proteins Deployed on Aerial Surfaces by Short Glandular Trichomes; Plant Cell 17 (2005) 1851-1861. DOI: 10.1105/tpc.105.031559

20. Kroumova, A.B., R.W. Shepherd, and G.J. Wagner: Impacts of T-Phylloplanin Gene Knockdown and of Helianthus and Datura phylloplanins on Perenospora tabacina Spore Germination and Disease Potential; Plant Physiol. 144 (2007) 1843-1851. DOI: 10.1104/ pp.107.097584

21. Shepherd, R.W. and G.J. Wagner: Fungi and Leaf Surfaces; in: Biocomplexity of Plant-Fungal Interactions; edited by D. Southworth, Wiley-Blackwell Press, New Jersey, USA, 2012, pp. 131-154.

22. King, B.C.: T-Phylloplanin and cis-Abienol, Two Natural Products from Tobacco Have Broad Spectrum, Anti-Fungal Activities; University of Kentucky Doctoral Dissertations, Paper 208, 2008. Available at: http:// 
uknowledge.uky.edu/gradschool_diss/208/ (Accessed June 30, 2016).

23. Severson, R.F., M.G. Stephenson, A.W Johnson, D.M. Jackson, and O.T. Chortyk: Isolation and Preparative Chromatography of the Major Cuticular Diterpenes of Green Tobacco; Tob. Sci. 32 (1988) 99-103.

24. Guo, Z., R.F. Severson, and G.J. Wagner: Biosynthesis of the Diterpene cis-Abienol in Cell-Free Extracts of Tobacco Trichomes; Arch. Biochem. Biophys. 308 (1994) 103-108. DOI:10.1006/abbi.1994.1015

25. Danehower, D.A. R.C. Long, C.P. Wilcox, A.K. Weissinger, T.A. Bartholomew, and H.E. Swaisgood: Tobacco as a Biochemical Resource: Past, Present, and Future; in: Biologically Active Natural Products: Agrochemicals; edited by H.G. Cutler and S.J. Cutler, CRC Press LLC, Boca Raton, Florida, USA, 1999, pp. 155-168. DOI: 10.1201/9781420048629.ch13

26. Harborne, J.B.: Systematic Significance of Variations in Defense Chemistry in the Solanaceae; in: Solanaceae - Biology and Systematics; edited by W.G. D'Arcy, Columbia University Press, New York, USA, 1986, pp. 328-344.

27. Guo, Z. and G.J. Wagner: Biosynthesis of Labdenediol and Sclareol in Cell-Free Extracts from Trichomes of Nicotiana glutinosa; Planta 197 (1995) 627-632. DOI: 10.1007/BF00191570

28. Caniard, A., P. Zerbe, S. Legrand, A. Cohade, N. Valot, J.L. Magnard, J. Bohlmann, and L. Legendre: Discovery and Functional Characterization of Two Diterpene Synthases for Sclareol Biosynthesis in Salvia sclarea (L.) and their Relevance for Perfume Manufacture; BMC Plant Biol. 12 (2012) 119-132. DOI: 10.1186/1471-2229-12-119

29. Seo, S., K. Gomi, H. Kaku, H. Abe, H. Seto, S. Nakatsu, M. Neya, M. Kobayashi, K. Nakaho, Y. Ichinose, I. Mitsuhara, and Y. Ohashi: Identification of Natural Diterpenes that Inhibit Bacterial Wilt Disease in Tobacco, Tomato and Arabidopsis; Plant Cell Physiol. 53 (2012) 1432-1444. DOI: 10.1093/pcp/ pcs085

30. Huang, G.J., C.H. Pan, and C.H. Wu: Sclareol Exhibits Anti-Inflammatory Activity in Both Lipopolysaccharide-Stimulated Macrophages and the $\lambda$ Carrageenan-Induced Paw Edema Model; J. Nat. Prod. 75 (2012) 54-59. DOI: 10.1021/np200512a

31. Chinou, I., C. Demetzos, C. Harvala, C. Roussakis, and J.F. Verbist: Cytotoxic and Antibacterial Labdane-Type Diterpenes from the Aerial Parts of Cistus incanus subsp. creticus; Planta Med. 60 (1994) 34-36. DOI: 10.1055/s-2006-959403

32. Dimas, K., C. Demetzos, M. Marsellos, R. Sotiriadou, M. Malamas, and D. Kokkinopoulos: Cytotoxic Activity of Labdane Type Diterpenes Against Human Leukemic Cell Lines In Vitro; Planta Med. 64 (1998) 208-211. DOI: $10.1055 / \mathrm{s}-2006-957410$

33. Shepherd, R.W.: Phylloplanins - Novel Antifungal Proteins on Plant Leaf Surfaces; University of Kentucky Doctoral Dissertations, Paper 763, 2010. Available at: http://uknowledge.uky.edu/gradschool_diss/763 (Accessed June 30, 2016).

34. Severson, R.F., R.F. Arrendale, O.T. Chortyk, C.R. Green, F.A. Thome, J.L. Stewart, and A.W. Johnson:
Isolation and Characterization of the Sucrose Esters of the Cuticular Waxes of Green Tobacco Leaf; J. Agric. Food Chem. 33 (1985) 870-875. DOI: 10.1021/jf000 $65 \mathrm{a} 026$

35. Jeffers, S.N. and S.B. Martin: Comparison of Two Media Selective for Phytophthora and Pythium Species; Plant Disease 70 (1986) 1038-1043. DOI: 10.1094/PD70-1038

36. Latham, D.H.: A Black Shank Resistant Dark FireCured Tobacco and Observations on Tobacco Black Shank in Tennessee; University of Tennessee, Agricultural Experiment Station, Bulletin, 1969, 1-13. Available at: http://trace.tennessee.edu/utk_agbulletin/149 (Accessed June 30, 2016).

37. Severson, R.F., R.V.W. Eckel, D.M. Jackson, V.A. Sisson, and M.G. Stephenson: Aphicidal Activity of Cuticular Components from Nicotiana tabacum; in: Natural and Engineered Pest Management Agents; edited by R.A. Heidin, J.J. Menn, and R.M. Hollingworth, ACS Symphosium Series, Washington DC, USA, Vol. 551, 1994, pp. 172-179. DOI: 10.1021/bk1994-0551.ch012

38. Menetrez, M.L., H.W. Spurr, D.A. Danehower, and D.R. Lawson: Influence of Tobacco Leaf Surface Chemicals on Germination of Peronospora tabacina adam sporangia; J. Chem. Ecol. 16 (1990) 1565-1576.

39. Kannwischer, M.E. and D.J. Mitchell: The Influence of a Fungicide on the Epidemiology of Black Shank of Tobacco; Phytopathology 68 (1978) 1760-1765.

40. Gutiérrez, W.A. and A.L. Mila: A Rapid Technique for Determination of Races of Phytophthora nicotianae on Tobacco; Plant Disease 91 (2007) 985-989. DOI:10.1094 / PDIS-91-8-0985

41. Csinos, A.S.: Stem and Root Resistance to Tobacco Black Shank; Plant Disease 83 (1999) 777-780. DOI: org/10.1094/PDIS.1999.83.8.777

42. Litton, C.C., G.B. Collins, and P.D. Legg: A Greenhouse Technique for Screening Tobacco Seedlings for Black Shank Resistance; Tob. Sci. 14 (1970) 124-125.

43. Kennedy, B.S., M.T. Nielsen, R.F. Severson, V.A. Sisson, M.K. Stephenson, and D.M. Jackson: Leaf surface chemicals from Nicotiana affecting germination of Peronospora tabacia (adam) sporangia; J. Chem. Ecol. 18(1992) 1467-1479. DOI: 10.1007/BF00993221

44. Hieda, T., Y. Mikami, Y. Obi, and T. Kisaki: Microbial Transformation of cis-Abienol; Agric. Biol. Chem. 46 (1982) 2249-2255. DOI: 10.1080/00021369.1982. 10865428

Corresponding author:

Antoaneta B. Kroumova

KTRDC, College of Agriculture

University of Kentucky

1401 University Drive

Lexington, KY 40546, USA

E-mail: amihaylo@uky.edu 